\title{
ENDODONTIC IRRIGANT DELIVERY SYSTEMS- A LITERATURE REVIEW
}

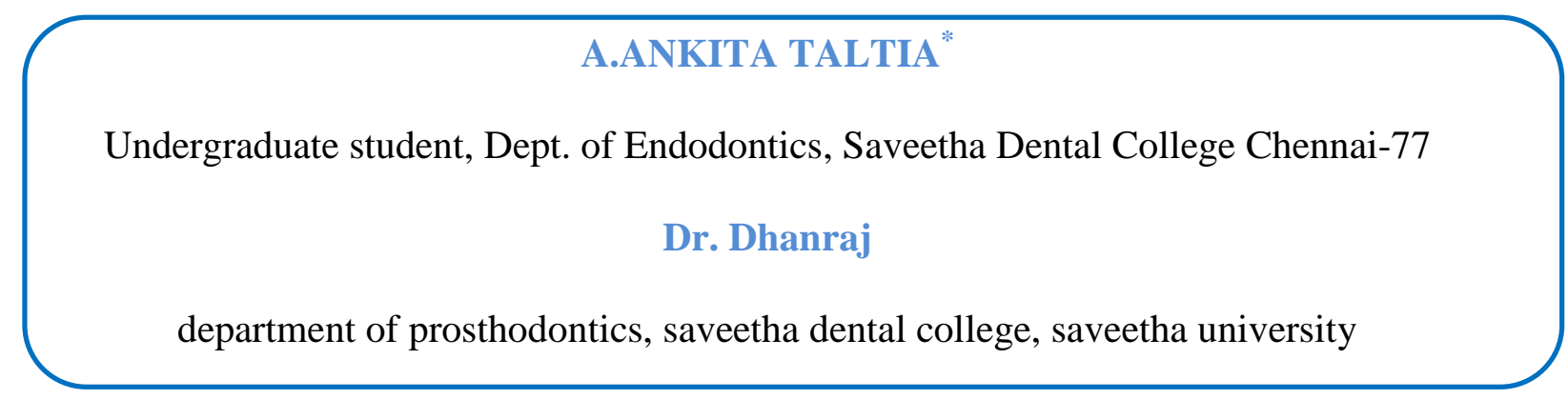

*CORRESPONDING AUTHOR:

\section{A.ANKITA TALTIA}

Saveetha Dental College, 162,PH road, Vellappanchavadi, Poonamallee, Chennai- 600077

\begin{abstract}
:
The ultimate goal of endodontic therapy is thorough debridement of all vital or necrotic tissue, microorganisms and their products from the root canal system. This can be achieved by chemomechanical debridement. However, irregular canal cross-sections, accessory canals, isthmuses, fins, curves and apical delta make chemomechanical debridement difficult. Hence irrigation of root canal sysytem is very essential. For effective action particularly for the apical portions of small root canals the irrigants must be brought into direct contact with the entire canal wall surfaces. Various irrigant delivery systems have been developed in order to provide effective delivery. The objective of this review is to present an overview of the various irrigant delivery systems available in endodontics. Recently developed irrigation devices and their applications are also discussed.
\end{abstract}

KEYWORDS: endodontic therapy, irrigants, irrigant delivery systems.

\section{INTRODUCTION:}

Removal of vital and necrotic remnants of pulp tissues, microorganisms, and microbial toxins from the root canal system $(1,2)$ is essential for a successful endodontic treatment. This can be achieved through chemo mechanical debridement but because root canal anatomy is intricate in nature, hence shaping and cleaning of the root canal completely is impossible (3). All the advanced and in research instrumentation systems and instruments like nickeltitanium instruments and rotary can only clean the central body of the canal. Canal structures like canal fins, isthmi, and cul-de-sacs are unscathed after completion of the preparation (4). These areas might be the probable places for containing microbes, their by-products and tissue debris which might prevent close adaptation of the obturation material and result in persistent periradicular inflammation (5). 
Essential part of root canal debridement is Irrigation which allows for cleaning beyond what might be achieved by root canal instrumentation alone. Dual irrigants such as sodium hypochlorite $(\mathrm{NaOCl})$ with EDTA or chlorhexidine $(\mathrm{CHX})$ are often used as initial and final rinses to complement the shortcomings that are associated with the use of a single irrigant as till date none of the irrigant possess ideal quality that is why in contemporary endodontic practice dual irrigants are used. For effective action particularly for the apical portions of small root canals the irrigants must be brought into direct contact with the entire canal wall surfaces.

Various irrigant delivery systems have been developed in order to provide effective delivery. These systems might be divided into 2 categories, manual agitation techniques and machineassisted agitation devices. The objective of this review is to present an overview of the various irrigant delivery systems available in endodontics.

\section{CONVENTIONAL IRRIGATION:}

Conventional irrigation with syringes is an efficient method of irrigant delivery before the advent of passive ultrasonic activation. The irrigant is dispensed either passively or with agitation into the canal through needles/cannulas of variable gauges. The needle is moved up and down the canal space for the latter. Irrigation tip gauge and tip design are the factors which affect the irrigation flow pattern, flow velocity, depth of penetration, and pressure on the walls and apex of the canal (6). Irrigation tip gauge will largely determine how deep an irrigant can penetrate into the canal. A 21-gauge tip can reach the apex of an ISO size 80 canal, a 23-gauge tip can reach a size 50, a 25-gauge tip can reach a size 35 canal and a 30gauge tip can reach the apex of a size 25 canal. 27 -gauge needle is the favoured needle tip size for the routine endodontic procedures. Several studies have shown that the irrigant has a limited effect beyond the tip of the needle due to the dead- water zone or sometimes air bubbles in the apical root canal, which prevent apical penetration of the solution $(7,8)$.

Plastic syringes of different sizes (1-20 mL) are most commonly used for irrigation. Syringes with larger volume allow some time-savings but they are more difficult to control for pressure and accidents may happen. Hence in order to maximize safety and control1-5ml syringes are widely recommended instead of the larger ones. Advantages of syringe irrigation includes easy control of the depth of needle penetration within the canal and the volume of irrigant flushed through the canal. On the other hand, the mechanical flushing action created by conventional hand-held syringe needle irrigation is comparatively weak. After the conventional syringe needle irrigation, canal extensions and irregularities which cannot be assessed are likely to harbour debris and bacteria, thereby making thorough canal debridement difficult.

\section{MAX-I-PROBE}

Max-i-probe is a modified regular manual irrigation needles with a well-rounded, close tip and side-port venting. The needles are available from 21 to 30 gauges. It has the luer lock 
connector. As per the manufacturer, the risk of perforating the apex is prevented by the rounded tip and the side-port which disperses the irrigating solution creates a unique upward turbulent motion, which thoroughly irrigates the root canal but prevents solution and debris from being transported through the periapical foramen. $(9,10)$

\section{NAVI TIP FX}

NaviTip Fx is a 30-gauge irrigation needle covered with a brush. Ultradent company introduced them initially. When compared to brushless NaviTip needle, this Brush is incorporated for debridement of the canal walls and agitation of root canal irrigant which was helpful in improved cleanliness of coronal third (10). However, the drawback of NaviTip FX brush bristles is, it may dislodge inside the canal irregularities and due to its radiolucent nature it is very difficult to identify it radiographically or even with the use of a surgical microscope. (11)

\section{MANUAL DYNAMIC IRRIGATION}

For an effective action an irrigant must be in direct contact with the canal walls. However, it is often difficult for the irrigant to reach the apical portion of the canal because of the supposed vapour lock effect. Research has shown that an effective hydrodynamic effect can be produced by a gently moving well-fitting gutta-percha master cone up and down in short 2 to $3 \mathrm{~mm}$ strokes within an instrumented canal and significantly improve the displacement and exchange of any given reagent. This was recently confirmed by the studies of McGill et al, and Huang et al. These studies verified that manual-dynamic irrigation was considerably more effective than an automated-dynamic irrigation system and static irrigation (12).

Although manual-dynamic irrigation is used as a canal irrigation due to its simplicity and cost- effectiveness, the laborious nature of this hand-activated procedure still hinders its application in routine clinical practice. (12).

\section{ROTARY BRUSH}

Both Ruddle brush and Canal Brush belong to this category.

I. A rotary hand piece-attached micro brush is used for debris and smear layer removal from instrumented root canals (13). The brush includes a shaft and a tapered brush section. From a central wire core multiple bristles extending radially. During the debridement phase, the bristles of the micro brush deform into the irregularities of the canal when they rotate at about $300 \mathrm{rpm}$. This helps to displace residual debris in a coronal direction of the canal. However, this product is not commercially available since the patent was approved in 2001.

II. Canal Brush is another endodontic micro brush that has recently been made commercially available. It is a highly flexible micro brushmoulded entirely from polypropylene and might be used manually with a rotary action. A study conducted by Weise et al., showed that debris 
was effectively removed from simulated canal extensions and irregularities with the use of the small and flexible CanalBrush with an irrigant (14).

\section{CONTINUOUS IRRIGATION DURING ROTARY IRRIGATION}

\section{THE QUANTEC-E IRRIGATION SYSTEM}

The Quantec-E irrigation system was first introduced by SybronEndo company. It is a selfcontained fluid delivery unit that is attached to the Quantec-E Endo System. It has a pump console, 2 irrigation reservoirs, and tubing to provide continuous irrigation during rotary instrumentation. Continuous irrigant agitation during active rotary instrumentation would generate an increased volume of irrigant which in turn will cause increase irrigant contact time and facilitate greater depth of irrigant penetration inside the root canal. This should result in more effective canal debridement compared with syringe needle irrigation. However studies conducted by Setlock et al (15) and Walters et al (16) proved that Quantec-E irrigation did result in more complete debris and smear layer removal in the coronal third of the canal walls and there was no significant difference between standard syringe needle irrigation and irrigation with the Quantec-E irrigation system.

\section{SONIC IRRIGATION}

Sonic instruments for endodontics were first reported by Tronstad et al. (17) It operates at a lower frequency $(1-6 \mathrm{kHz})$ and also produces smaller shear stresses than ultrasonic irrigation Ahmed et al. (18).

\section{THE VIBRINGE SYSTEM}

The Vibringe System was first introduced by B.V. Vibringe that combines manual delivery and sonic activation of the solution in one step. The Vibringe is a cordless hand piece that fits in a special disposable 10 -mL Luer-Lock syringe that is compatible with every irrigation needle. The irrigant is sonically activated, as is the needle that attaches to the syringe. Rödig et al (19) evaluated the efficacy of Vibringe system and concluded that Vibringe system showed significantly better results than syringe irrigation in removing debris in the apical third. However, it was not as effective as the passive ultra-sonic irrigation.

\section{THE ENDOACTIVATOR SYSTEM}

The EndoActivator is a recently introduced sonically driven canal irrigation system. The parts of an EndoActivator includes a cordless, contra- angled, three-speed, battery- operated hand piece and 3 types of disposable polymer tips of different sizes. The tips are made from a medical-grade polymer and are claimed to be strong and flexible and do not break easily. They are color-coded as yellow, red, and blue, closely corresponding to sizes 15/02, 25/04, and 35/04, respectively. They are smooth and do not cut dentin. Vibrating the tip at 10,000 cycles per minute (cpm) along with moving the tip up and down in short strokes, produces a powerful hydrodynamic phenomenon. This action improves the flow of irrigant into the 
more inaccessible regions of the root canal system.(20). It is also helpful in delivering mineral trioxide aggregate into blunderbuss canals, in straight or curved canals, and in the retreatment situation to break up and dislodge remnants of obturation materials.

Studies have shown that agitating a solution is a more effective method of removing calcium hydroxide from a prepared canal.(21). The EndoActivator System has shown effective cleaning of debris from lateral canals, removal of the smear layer, and dislodgement of clumps of simulated biofilm within the curved canals.(22)

\section{ULTRASONIC IRRIGATION}

Ultrasonics is another group of instruments that can be used for irrigation in the ultrasonic and subsonic hand pieces. The ultrasonic hand pieces cause the vibration of the endodontic file at 25,000 vibration/s. Studies have demonstrated that by using ultrasonic and sonic devices that show acoustic micro-streaming and cavitation, effective delivery of irrigants to the apical third of the canal can be enhanced. Acoustic micro-streaming is the movement of fluids along cell membranes as a result mechanical pressure changes within the tissue created by the ultrasound energy. Cavitation is the formation and collapse of gas and vapour-filled bubbles or cavities in a fluid. There are two types of ultrasonic irrigation. The first type of ultrasonic irrigation is a combination of simultaneous ultrasonic instrumentation and irrigation (UI) and the second type works without simultaneous instrumentation and is referred to as passive ultrasonic irrigation (PUI).

Passive ultrasonic irrigation is more effective than conventional syringe irrigation in removing dentine debris and pulpal tissue remnants. This can be attributed to the fact that ultrasonic irrigation causes a much higher velocity and volume of irrigant flow created in the canal. However, ultrasonic irrigation cannot effectively get through the apical vapour lock (23-25).

\section{PRESSURE ALTERNATION DEVICES}

The RinsEndo irrigation system and the EndoVac irrigation system are examples of negativepressure irrigation.

\section{THE RINSENDO IRRIGATION SYSTEM}

This system irrigates the canal by using pressure-suction technology. It consists of a hand piece, a syringe carrying irrigant and a cannula with a $7 \mathrm{~mm}$-long exit aperture.(26) The hand piece has an irrigation speed of $6.2 \mathrm{ml} / \mathrm{min}$. From an attached syringe, $65 \mathrm{~mL}$ of a rinsing solution oscillating at a frequency of $1.6 \mathrm{~Hz}$ and is transported to the canal via an adapted cannula. Used solution and air are recollected from the root canal and automatically merged with fresh rinsing solution during suction phase. The pressure-suction cycles continue for approximately 100 times per minute.(9) The pulsating nature of the fluid flow, helps to rinse the apical third of the canal, with the cannula restricted to the coronal third of the root canal. 
However it is found to be less effective in removing the stained collagen from root canal walls and has high risk of apical extrusion of irrigant.(12)

\section{THE ENDOVAC APICAL NEGATIVE-PRESSURE}

The EndoVac system was first proposed by Dr. G. John to effectively irrigate and remove debris up to the apical constriction without forcing solution out the apex into the periapical tissue.

It contains three basic components: 1) A Hi-Vac adapter assembly that connects to the high volume evacuation hose in the dental operatory at one end and has a " $\mathrm{T}$ " connector at the other end which permits a Master Delivery irrigation- suction tip (MDT) with a disposable syringe filled with irrigation solution, 2) The Macro cannulaand 3)the Micro cannula. The MDT delivers irrigant. During irrigation, the Master Delivery Tip delivers irrigant to the pulp chamber and removes excess irrigant. Both the cannulas exert negative pressure that pulls fresh irrigant from the chamber. Thus, a constant flow of fresh irrigant is delivered by negative pressure to the working length of the canal. Apical negative pressure enables the irrigants to reach the apical third and help overcome apical vapour lock.

Nielsen and Baumgartner(26) compared the efficacy of the EndoVac system and Needle irrigation to debride the apical $3 \mathrm{~mm}$ of a root canal. No significant difference between the two irrigation techniques was noted at the apical $3 \mathrm{~mm}$ level. But at $1 \mathrm{~mm}$ apical level, the EndoVac system significantly resulted in less remaining debris. The EndoVac irrigation system was also shown to achieve better microbial control than the traditional irrigation delivery system (Hockett et al, Miller and Baumgartner) (27). Another in vitro study indicated that EndoVac left significantly less debris behind than the conventional 30-gauge needle irrigation methods (Shin et al.) (28).

In contrast, two very recent studies showed the opposite results. The first by Townsend and Maki who conducted a study on plastic simulated canals, found that the EndoVac irrigation system was significantly less effective in removing bacteria when compared with ultrasonic irrigation (29). Another study conducted by Brito et alfound no significant difference in bacterial reduction efficiency between the EndoVac system, the Navi Tip needle and the Endo Activator sonic system. (30)

\section{SELF ADJUSTING FILE- THE VATEA SYSTEM}

The SAF file is a hollow tube with its walls made from a thin nickel titanium lattice with a rough outer surface and is the first file that does not have a solid metal shaft. The VATEA system is an irrigation device which is an integral part of the SAF. The VATEA system is a self-contained, fluid delivery unit intended to be attached to dental hand pieces to deliver irrigants during endodontic procedures. The SAF file has a freely rotating hub connected to a disposable polyethylene tube. Irrigation solution is pumped from the VATEA's reservoir to this tube which allows the irrigant to flow through the hollow file to the root canal. The flow 
rate at which the irrigant can be delivered into the tube can be controlled by the operator using the $-/+$ push buttons located on the control panel and it ranges from $1-10 \mathrm{~mL}$ per minute, with recommended setting of $4 \mathrm{~mL}$ per minute.

The SAF System is based on a no pressure irrigation system that is active throughout the instrumentation process.(31) Once the irrigant enters the SAF, due to the lattice structure of the file, any pressure that is existing in the delivery tube disappears. The vibrations of the file along with its pecking motion result in the continuous mixing of the irrigant present in the root canal with fresh, fully active irrigant. The SAF system also provides the scrubbing effect which is not possible with PUI or EndoVac system. Highly effective cleaning of the canal walls can be achieved by combined scrubbing with the continuous flow of fresh, fully chemically active sodium hypochlorite.SAF can be more effective for irrigating curved canals, oval canals and c-shaped canals. A recent study by Prof. Jose Siqueira from Estácio de Sá University, Brazil, indicated that in oval canals the SAF SYSTEM was found superior to rotary $\mathrm{Ni}$-Ti files used with needle irrigation $(\mathrm{NaOCl})$.

\section{ENDO IRRIGATOR PLUS (K DENT DENTAL SYSTEM)}

This product was first designed by Dr Mandar Pimprikar. It is based on activated continuous warm irrigation and evacuation system(ACWIS). Trials done under electronic microscope have found out that this device helps penetration of Sodium Hypochlorite Solution into the lateral and accessories canals. Strong vacuum evacuation system insures that Sodium Hypochlorite doesn't reach the periapical region and hence does not harm or damage the periapical tissues. This device creates positive and negative pressure inside the canal. This gives a perfect cleaning and disinfection of root canal assisted by negative and positive pressure with warm Sodium hypochlorite solution

\section{CONCLUSION}

Irrigation has a key role in successful endodontic treatment. Although $\mathrm{NaOCl}$ is the most important irrigating solution, no single irrigant can accomplish all the tasks required by irrigation. Technological advances like positive and negative irrigation have brought to fruition new devices that rely on various mechanisms of irrigant transfer, soft tissue debridement and, depending on treatment philosophy, removal of smear layers. Negative irrigation is although more superior to positive pressure irrigation as prevent periapical extrusion of irrigant, provides better cleansing, has no vapour lock effect and provides adequate irrigant volume but still further research is warranted.

\section{REFERENCES:}

1. Wong R. Conventional endodontic failure and retreatment. Dent Clin North Am 2004;48:265-89.

2. Basmadjian-Charles CL, Farge P, Bourgeois DM, Lebrun .Factors influencing the longterm results of endodontic treatment: review of the literature. Int Dent J 2002; 52:81-6. 
3. Ferreira RB, Alfredo E, Porto de Arruda M, Silva Sousa YT, Sousa-Neto MD. Histological analysis of the cleaning capacity ofnickel-titanium rotary instrumentation with ultrasonic irrigation in root canals. AustEndod J 2004;30:56-8.

4. Walton RE. Histologic evaluation of different methods of enlarging the pulp canal space. J Endod 1976;2:304-11.

5. Naidorf IJ. Clinical microbiology in endodontics. Dent Clin North Am 1974;18: 32944.

6. Boutsioukis C, Gogos C, Verhaagen B, Versluis M, Kastri-nakis E, Van der Sluis LW. The effect of root canal taper on the irrigant flow: evaluation using an unsteady Computational Fluid Dynamics model. IntEndod J. 2010;43(10):909- 16.

7. Boutsioukis C, Gogos C, Verhaagen B, Versluis M, Kastri-nakis E, Van der Sluis LW. The effect of apical preparation size on irrigant flow in root canals evaluated using an unsteady Computational Fluid Dynamics model. IntEndod J. 2010;43(10):874-81.

8. Markus Haapasalo, et al., Irrigation in Endodontics. Dent Clin N Am. 2010;54:291- 312.

9. Gu LS, Kim JR, Ling J, Choi KK, Pashley DH, Tay FR. Review of contemporary irrigant agitation techniques and devices. J Endod. 2009;35: 791804. Review.

10. Dr. Deenadayalan Elumalai1, Dr. Ashok Kumar, Dr. Rajendra K Tewari, Dr.Surendra K Mishra, Dr. Huma Iftekhar, Dr. ShariqueAlam, Dr.MukhtarAndrabi, "Newer Endodontic irrigation devices: An update", IOSR Journal of Dental and Medical Sciences (IOSR JDMS), Volume 13, Issue 6 Ver. V (Jun. 2014), PP 04-08

11. Al-Hadlaq SM, Al-Turaiki SA, Al-Sulami U, Saad AY. Effi-cacy of new brush- covered irrigation needle in removing root canal debris: a scanning electron microscopic study. $J$ Endod. 2006;32(12):1181-84.

12. McGill S, Gulabivala K, Mordan N, Ng YL The efficacy of dynamic irrigation using a commercially available system (RinsEndo) determined by removal of a collagen 'biomolecular film' from an ex vivo model. IntEndod J.2008 41, 6028.

13. Ruddle CJ. Microbrush for endodontic use. Washington, DC: United States Patent 6,179,617; 2001.

14. Weise M, Roggendorf MJ, Ebert J, Petschelt A, Frankenberger R. Four methods for cleaning simulated lateral extensions of curved root canals: a SEM evaluation. IntEndod J. 2007;40:991-92

15. Setlock J, Fayad MI, BeGole E, Bruzick M. Evaluation of canal cleanliness and smear layer removal after the use of the Quantec-Eirrigation system and syringe: a comparative scanning electron microscope study. Oral Surg Oral Med Oral Pathol Oral RadiolEndod 2003;96:614-7.

16. Walters MJ, Baumgartner JC, Marshall JG. Efficacy of irrigation with rotary instrumentation. J Endod 2002;28:837-9.

17. Tronstad L, Barnett F, Schwartzben L, Frasca P. Effectiveness and safety of a sonic vibratory endodontic instrument. Endod Dent Traumatol. 1985;1:69-76. 90.

18. Ahmad M, Pitt Ford TR, Crum LA. Ultrasonic debridement of root canals: an insight into the mechanisms involved. $J$ Endod. 1987;13:93-101. 
19. Rödig T, Bozkurt M, Konietschke F, Hülsmann M. Comparison of the Vibringe system with syringe and passive ultrasonicirrigation in removing debris from simulated root canal irregularities. J Endod 2010;36:1410-1413.

20. Guerisoli DM, Marchesan MA, Walmsley AD, Lumley PJ: Evaluation of smear layer removal by EDTAC and so- dium hypochlorite with ultrasonic agitation, IntEndod J 35:5, pp. 418-421, 2002.

21. van der Sluis LWM, Wu MK, Wesselink PR: The evaluation of removal of calcium hydroxide paste from an artificial standardized groove in the apical root canal using different irrigation methodologies, IntEndod J 40:1, pp. 52-57, 2007.

22. Caron G. Cleaning efficiency of the apical millimeters of curved canals using three different modalities of irrigant activation: an SEM study. Paris VII University, Paris, France: Mastersthesis; 2007.

23. Walker TL, del Rio CE. Histological evaluation of ultrasonic and sonic instrumentation of curved root canals. J Endod. 1989;15:49-59.

24. Burleson A, Nusstein J, Reader A, Beck M. The in vivo eval-uation of hand/ rotary/ultrasound instrumentation in necrotic, human mandibular molars. $J$ Endod. 2007;33(7):782-87.

25. Dr. Deenadayalan Elumalai1, Dr. Ashok Kumar, Dr. Rajendra K Tewari, Dr.Surendra K Mishra, Dr. Huma Iftekhar, Dr. ShariqueAlam, Dr.MukhtarAndrabi, "Newer Endodontic irrigation devices: An update", IOSR Journal of Dental and Medical Sciences (IOSR JDMS), Volume 13, Issue 6 Ver. V (Jun. 2014), PP 04-08

26. Nielsen BA, Craig Baumgartner J. Comparison of the Endo-Vac system to needle irrigation of root canals. J Endod. 2007;33(5):611-15.

27. Hockett JL, Dommisch JK, Johnson JD, Cohenca N. Antimi-crobial efficacy of two irrigation techniques in tapered and nonta-pered canal preparations: an in vitro study. $J$ Endod. 2008;34(11):1374-77.

28. Shin SJ, Kim HK, Jung IY, et al. Comparison of the cleaning efficacy of a new apical negative pressure irrigating system with conventional irrigation needles in the root canals. Oral Surg Oral Med Oral Pathol Oral RadiolEndod. 2010;109(3):479-84.

29. Townsend C, Maki J. An In Vitro Comparison of New Irrigation and Agitation Techniques to Ultrasonic Agitation in Removing Bacteria From a Simulated Root Canal. J Endod. 2009;35:1040-43.

30. Brito PR, Souza LC, Machado de Oliveira JC, et al.,. Comparison of the effectiveness of three irrigation techniques in reducing intracanal Enterococcus faecalis populations: an in vitro study. J Endod. 2009;35(10):1422-27.

31. Zvi Metzger, "The selfadjusting file (SAF) system: An evidencebased update", J Conserv Dent 2014,17:401-19. 